\title{
The role of edaphic, vegetational and spatial factors in structuring soil animal communities in a floodplain forest of the Dnipro river
}

\author{
Oleksandr V. Zhukov*, Olga M. Kunah, Yuliya Y. Dubinina, Viktoriya O. Novikova
}

Department of Zoology and Ecology, Faculty of Biology and Ecology, Oles Honchar Dnipro National University, Gagarin Ave. 72, Dnipro, 49010, Ukraine

\begin{abstract}
Zhukov, O.V., Kunah, O.M., Dubinina, Y.Y., Novikova, V.O., 2018. The role of edaphic, vegetational and spatial factors in structuring soil animal communities in a floodplain forest of the Dnipro river. Folia Oecologica, 45: 8-23.

This paper examines the role of ecological factors, derived from principal component analysis performed on edaphic and vegetational dataset as well as spatial variables, in structuring the soil macrofauna community of the Dnipro floodplain within the 'Dnipro-Orilsky' Nature Reserve (Ukraine). The soil macrofauna was defined as invertebrates visible to the naked eye (macroscopic organisms). The test points formed a regular grid with a mesh size of $3 \mathrm{~m}$ with $7 \times 15$ dimensions. Thus, the total test point number was 105 . At each point, soil-zoological samples of $0.25 \times 0.25 \mathrm{~m}$ were taken for quantifying the soil macrofauna. The spatial structure was modeled by a set of independent spatial patterns obtained by means of principal coordinates of neighbor matrices analysis (PCNM-variables). Spatial PCNM-variables explain significantly more variations of the community $(19.9 \%)$ than edaphic factors $(4.1 \%)$ and vegetation factors $(3.2 \%)$. Spatial and combined environmental and spatial effects were divided into three components: broad-scale component was characterized by periodicity of spatial variation with a wavelength of $24.0-44.5 \mathrm{~m}$, medium-scale $-11.1-20 \mathrm{~m}$, fine-scale 6.6-11.0 m. For a broad-scale component, environmental factors of a vegetational nature are more important, for medium-scale, edaphic factors are more important, for fine-scale, both vegetation and edaphic are important. For litter-dwelling animals, the most characteristic spatial patterns are on the broad and medium-scale levels. For endogeic and anecic animals, the most significant variability is on the fine-scale level.
\end{abstract}

\section{Keywords}

ecological groups, ecological niche, environmental factors, neutral diversity, spatial variation

\section{Introduction}

Spatial and ecological gradients influence the spatial variation of species diversity and the community structure (Lawton, 1999; Hubbell, 2001). Beta diversity is defined as the difference in the species composition of a community between two or more sites (WhITTAKER, 1960, 1972; LEGENDRE et al., 2005). This concept plays a key role in identifying and understanding the patterns of diversity at different hierarchical levels (SoINENEN et al., 2007). The mechanisms governing the beta diversity are either deterministic or stochastic processes (BAROT and GignOUX, 2004; LALiBerte et al., 2009). Assessment of the role of each of these factors finds its expression in the debate between the theory of ecological niche and the theory of neutral diversity (HutCHINSON, 1957; HubBELL, 2001; AdLER et al., 2007; ClARK, 2012). In accordance with the theory of ecological niche, two spatially close local communities are affected by similar environmental conditions which define the spatial patterns of resources

*Corresponding author:

e-mail: zhukov_dnipro@ukr.net 
and conditions underlying the spatial autocorrelation of the community. In its turn, the theory of neutrality also predicts that, by increasing the geographical distance, the differences between communities will also increase, ie. neutral dynamics are also capable of generating spatial autocorrelation (CARUSO et al., 2012). The key difference between the deterministic and neutral dynamics is that the latter determine spatial patterns regardless of changes in environmental properties (Hubbell, 2001; Chave, 2004; Dornelas et al., 2006; Dornelas, 2010). Splitting environmental variables and spatial descriptors, obtained on the basis of geographical coordinates, into individual and combined components, and then making an assessment of how these variables correlate with the variability of the composition of the community or with its diversity (the so-called variation partitions - BORCARD et al., 1992; LEGENDRE et al., 2009), makes it possible to identify the role of neutral and niche-dependent mechanisms. If spatial autocorrelation cannot be explained by environmental factors, then it is viewed as the result of the action of neutral mechanisms, such as the specific dispersal limitation (Legendre et al., 2009; Hu et al., 2013; Siefert et al., 2013). Environmental processes are determined by impacts at various scale levels, ranging from local to global (Legendre, 1993; YorkinA et al., 2018). The spatial patterns observed in natural communities are the result of environmental factors, and they are determined by biological and/or historical causes (DraY et al., 2006). The effects of these causes are not mutually exclusive, but rather complementary (JiMÉNEZ et al., 2014). The existence of spatial structures in species complexes involves action of at least one structuring factor. Among the structuring factors, there are spatially distributed environmental factors structuring communities in accordance with the theory of ecological niche (Hutchinson, 1957, 1965). Interspecies interactions may lead to two opposite types of dynamics. Strong interactions can make a community either deterministic or historically conditioned (CHASE, 2003). It has been suggested that ecological heterogeneity is of the greatest importance for the structuring of complexes on a wide scale, whereas stochastic processes, such as dispersion, operate on more distinct fine-scale levels (LEGENDRE, 1993; LALIBERTE et al., 2009; Gazol and IBANEZ, 2010).

In accordance with the deterministic point of view, the environmental conditions determine which of the species within a regional pool will remain in the community as a result of species interactions. In this case, the history of immigration does not affect the final composition of the species. If the community is historically conditioned, the environmental conditions do not define a single climax community (FuKami, 2010). The role for the community of such spatial characteristics as the size of sites where the community is represented, the level of its isolation and spatial heterogeneity, depends on the spatial scale of the ability of a species to move (CADOTTE and FuKAMI, 2005).

Geostatistics provides an opportunity to assess spatial distribution of the variability of environmental prop- erties and soil organisms (Rossi et al., 1996; Rossi et al., 2003). However, in order to model spatial structures at different scale levels, other statistical tools are needed, which can include the analysis of the principal coordinates of neighborhood matrices (principal coordinates of neighbor matrices - PCNM) (DRAY et al., 2006; BorCARD and LEGENDRE, 1994; BORCARD et al., 2004). This approach allows one to relate the variation of environmental properties to the community structure at various spatial levels (Rossi et al., 1996; BorCARD and Legendre, 1994).

Communities of soil organisms are structured on the basis of their response to the spatial variability of soil resources (Drake, 1990; Blanchet et al., 2013; DeCAËNS et al., 2009; JiMÉNEZ et al., 2012). Spatial heterogeneity creates conditions for the coexistence of competing species (JimÉNEZ et al., 2012; AMARASEKARE, 2003). It has been shown that soil-inhabiting invertebrates form spatial patterns which vary in range from the dimensions of individual aggregates (EtTema and Yeates, 2003) to the size of individual plants (Rossi et al., 1996), agricultural fields and natural ecosystems (DECAËNS and RosSI, 2001; RossI, 2003; Whalen, 2004). Individual species differ in their degree of aggregation (MCARDLE and ANDERSON, 2004), therefore neutral processes for different species can be observed at different scale levels (ANDERSON et al., 2011).

The nature of environmental gradients in soil as a habitat for living organisms is an important problem. Along with relief as a factor affecting redistribution of climate resources, factors of a phytogenic and zoogenic nature act as sources of heterogeneity of soil properties (KARPACHEVSKY, 2005). The influence of mesorelief appears on a broad scale, but phytogenic and zoogenic effects appear on a broad-scale, on a fine-scale and on a medium-scale level (ZHuKov et al., 2013). In their turn, spatial patterns of vegetational or pedoturbation activity of animals can have a neutral character. In this way, one cannot deny that factors of heterogeneity of ecological properties of the soil are by their nature generated by neutral causes. Therefore, we consider the assessment of the ratio of spatial factors as a highly relevant problem, as well as factors of an edaphic and vegetational nature in the organization of the community of soil macrofauna.

Soil ecosystems are rich in species. However, until now the reason for such species diversity remains unknown (WARDLE, 2006). It is assumed that soil animals are characterized by low specialization, which is more significant for other less diverse ecosystems (ANDERSON, 1975; Maraun et al., 2003; Digel et al., 2014). The high diversity of soil ecosystems is due to the three-dimensional nature of the soil body and small-scale resources gradients and conditions, which allows the maintenance of a high level of divergence of ecological niches (TAKEDA, 1987; Berg and Bengtsson, 2007). It is also possible that in reality the animals have much more distinctive trophic preferences than it was suggested earlier (JORGENSEN et al., 2003; SchneIDER et al., 2004). The structure of soil animal communities demonstrates significant variability at the micro level $(<1 \mathrm{~m})$. In the formation of such a 
mosaic, the following properties of the soil play an active role: the structure of pore space, soil microclimate, the structure of plants' root systems and the structure of terrestrial vegetation cover (BERG and BENGTSSON, 2007; Berg, 2012; Viketoft, 2013). Soil organisms are also characterized by spatial patterns at the meso-level (1-100 m) (SAEtre, 1999; EtTema et al., 2000; Jimenez et al., 2006; WidENFALK et al., 2015). At this level, the following environmental properties are important: gradients of soil $\mathrm{pH}$, humidity and composition of vegetation cover (ETTEMA and WARDLE, 2002; BerG, 2012). No statistically significant relationship was found between the occurrence of epigeic macrofauna and the microclimate of the studied forest stands (LAZORíK and KULA, 2015). The moisture content of soils plays an important role for soil macrofauna community structuring (NEKOLA, 2003), however, ONDINA et al. (2004) note the limited data on the role of soil moisture at a given time in view of the significant variability of this parameter. To solve this problem, it is appropriate to use phytoindication data to assess the soil animal communities' structure (HorsÁK et al., 2007; DvoŘÁKoví and Horsák, 2012). The changed density of a mature forest by previous thinning may significantly influence the structure of the studied communities of epigeic macrofauna when a very intensive thinning is used (StašIov and Svitok, 2014). The phytoindicator values and ecomorphs indexes, both derived from information about plant cover, were chosen as ecological factors influencing the mechanical impedance of the soil. Plant indicator values were shown to be capable of explaining the mechanical impedance of the soil at different levels of the spatial hierarchy (ZHUKOV and ZADOROZHNAYA, 2016). For favourable course of biological processes as well as the life of soil organisms and plant roots, it is important to provide a sufficient supply of water and air into the soil (Polláková et al., 2017). Soil animals are very sensitive to ecological conditions (IGONDOvá and MaJZlan, 2015). Soil mechanical impedance, electrical conductivity of the soil, soil temperature, and soil aggregate structure are important and ecologically relevant soil properties (KARPACHEVSKY, 2005) which may be used to explain soil animals' community structure (ZHUKOv et al., 2013; ZHUKOv et al., 2016).

In this study, we aimed to: i) test the importance of environmental factors in comparison with spatial factors for structuring soil macrofauna communities, ii) test the hypotheses that the role of the edaphic and vegetational factors is dependent on the spatial level, iii) test the hypothesis that sensitivity of the soil macrofauna to variability of the spatial scale depends on the soil animal lifeforms.

\section{Materials and methods}

\section{Site description}

The research was carried out in May 2016 in the 'Dniprovsko-Orilsky' Nature Reserve. The study polygon is located on the floodplain of the Dnipro river $\left(48^{\circ} 30^{\prime} 6^{\prime \prime} \mathrm{N}\right.$, $\left.34^{\circ} 47^{\prime} 18^{\prime \prime} \mathrm{E}\right)$. The habitat type is floodplain oak forest (EUNIS - G1.225 Sarmatic riverine [Quercus] forests, CORINE - 44.42 Residual medio-European fluvial forests, Pal. Hab. - 44.45 Sarmatic riverine oak forests, Natura 2000 - 91F0 Riparian mixed forests of Quercus robur, Ulmus leavis and Ulmus minor, Fraxinus excelsior or Fraxinus anguistifolia, along great rivers Ulmenion minoris) (DidukH et al., 2011). The type of soil is Greyic Fluvisol (Calcaric Eutric Arenic) (alluvial sod forest layered normal gleyic soil) (ZHUKOv et al., 2017). The level of groundwater was at a depth of $171 \mathrm{~cm}$. The surface of the soil was intensely dug up by wild boar. The mean annual temperature is $8.8^{\circ} \mathrm{C}$, the mean annual rainfall is 503.2 $\mathrm{mm}$. We used the data from the meteorological observatory of the city Dnipro.

\section{Sampling methods}

The polygon consists of 7 transects. Each transect is made up of 15 sampling points (Figure 1). The distance between the rows within the polygon is $3 \mathrm{~m}$.

\begin{tabular}{|c|c|c|c|c|c|c|c|c|c|c|c|c|c|c|}
\hline 91 & 92 & 93 & 94 & 95 & 96 & 97 & 98 & 99 & 100 & 101 & 102 & 103 & 104 & 105 \\
\hline 76 & 77 & 78 & 79 & 80 & 81 & 82 & 83 & 84 & 85 & 86 & 87 & 88 & 89 & 90 \\
\hline 61 & 62 & 63 & 64 & 65 & 66 & 67 & 68 & 69 & 70 & 71 & 72 & 73 & 74 & 75 \\
\hline 46 & 47 & 48 & 49 & 50 & 51 & 52 & 53 & 54 & 55 & 56 & 57 & 58 & 59 & 60 \\
\hline 31 & 32 & 33 & 34 & 35 & 36 & 37 & 38 & 39 & 40 & 41 & 42 & 43 & 44 & 45 \\
\hline 16 & 17 & 18 & 19 & 20 & 21 & 22 & 23 & 24 & 25 & 26 & 27 & 28 & 29 & 30 \\
\hline 1 & 2 & 3 & 4 & 5 & 6 & 7 & 8 & ? & 10 & 11 & 12 & 13 & 14 & 15 \\
\hline
\end{tabular}

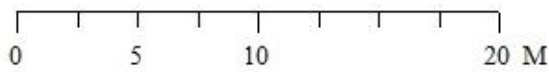

Fig. 1. The scheme for placing sample points within the study site. 
Soil macrofauna was defined as invertebrates visible to the naked eye (macroscopic organisms) (WARREN and Zou, 2002). Geobionts (large soil invertebrates that permanently inhabit the soil) and geophiles (organisms that live in the soil only for particular phases of their lives) (KRIVOLUTSKY, 1992; GHOLAMI et al., 2016) were assessed. Each sample consisted of a single block of soil, $25 \times 25 \times$ $30 \mathrm{~cm}^{3}$ deep, dug out quickly. A quadrat was fixed on the soil surface prior to taking the soil samples. The litter macrofauna was manually collected from the soil samples. The soil macrofauna were sorted and the animals were stored in 4\% formaldehyde (MATHIEU et al., 2004).

\section{Vegetation survey and plant variables}

A geobotanical description of the vegetation was made for each $3 \times 3 \mathrm{~m}$ quadrat. The overall list of vascular plants identified within the polygon totals 60 species (8.7 species at one plot) (ZHukov et al., 2017). TSATSENKIN (1970) believes that for reliable synphytoindication, 5 species of plants will be enough for a description. Thus, the species richness of vegetation cover is at a sufficient level to use phytoindicational assessment for describing the spatial variation of the edaphic and climatic properties of the habitat. The forest type according to BELGARD $(1950,1971)$ is xeromesophilic fresh elm-oak with snakeroot $\mathrm{D}_{\mathrm{e}}{ }{ }_{1-2}$. Based on the geobotanical descriptions, a phytoindicative assessment of the environmental factors according to BELGARD $(1950,1971)$, DIDUKH $(2011,2012)$ and ELLENBERG (1974) was made.

The plant ecomorphs are given according to BELGARD $(1950,1971)$ and TARASOV (2012). The coenomorphs are represented by stepants St (steppe species), pratants Pr (meadow species), psammophytes Ps, silvants Sil (forest species) and ruderants Ru.

Hygromorphs are represented by xerophytes (humidity level 1), mesoxerophytes (humidity level 2), xeromesophytes (humidity level 3), mesophytes (humidity level 4), hygromesophytes (humidity level 5). The humidity level by hygromorphic structure ( $\mathrm{Hygr}$ ) is estimated as (ZHUKOV and ZADOROZHNAYA, 2016):

$$
\text { Hygr }=\frac{\sum_{i=1}^{i=N}\left(i \times P_{i}\right)}{100},
$$

where $i$ is the moisture level, $P_{i}$ is the projective cover of plants of the corresponding hygromorph.

Trophomorphs are represented by oligotrophs (trophic level 1), mesotrophs (trophic level 2) and megatrophs (trophic level 3). Nutrient status level by trophomorphic structure (Troph) is estimated as:

$$
\text { Troph_B }=\frac{\sum_{j=1}^{j=N}\left(j \times P_{j}\right)}{100},
$$

where $j$ is the level of trophicity, $P_{j}$ is the projective plant cover of the corresponding trophomorph.

Heliomorphs are represented by heliosciophytes (level of light 2), scioheliophytes (level of light 3), helophytes (level of light 4). The level of illumination by the heliomorphic structure $(\mathrm{Hel})$ is estimated as:

$$
H e l=\frac{\sum_{z=1}^{Z=N}\left(z \times P_{z}\right)}{100},
$$

where $z$ is level of light, $P_{z}$ is the projective plant cover of the corresponding heliomorph.

Didukh phytoindication scales (DIDUKH, 2011, 2012) include edaphic and climatic scales. The edaphic phytoindication scales include the soil water regime $(\mathrm{Hd})$, the variability of humidity (fH), the soil aeration (Ae), the soil acidity ( $\mathrm{Rc})$, the total salt regime ( $\mathrm{Sl}$ ), the carbonate content in the soil $(\mathrm{Ca})$ and nitrogen content in the soil $(\mathrm{Nt})$. The climatic scales include the parameters of the thermal climate (thermal regime, Tm), humidity $(\mathrm{Om})$, cryo-climate $(\mathrm{Cr})$ and the continentality of climate $(\mathrm{Kn})$. In addition to these, the lighting scale (Lc) is indicated, which is characterized as a microclimate scale. Thermal properties of the soils are indicated by the thermal regime scale, and the hydrothermal properties by the ombro regime scale. Phytoindicational assessment of environmental factors was performed by the ideal indicator method of BUZUK (2017).

Ellenberg indicator values (ELLENBERG, 1974) include: $L$-scale of illumination/shading ( 9 classes, Light Regime), $T$-scale of thermoclimate ( 9 classes, Temperatures), $K$-scale of climate continentality ( 9 classes, Continentality of Climate), $F$-scale of soil humidity (9 classes, Humidity), $R$-scale of soil acidity ( 9 classes, Acidity), and $N$-scale of soil nitrogen ( 9 classes, Nutrients Availability). Estimation of the values of the environmental factors was carried out using the method of average weighted values of the indicator scales taking into account the projective cover of the plants.

Raunkier's life forms (RAUNKIER, 1934) include: phanerophytes $(\mathrm{Ph})$, nanophanerophytes $(\mathrm{nPh})$, hemicryptophytes $(\mathrm{HKr})$, therophytes $(\mathrm{T})$; geophytes $(\mathrm{G})$.

\section{Soil variables}

Measurement of soil mechanical impedance was carried out in the field using a hand penetrometer Eijkelkamp, to a depth of $100 \mathrm{~cm}$ at intervals of $5 \mathrm{~cm}$. The average error of the measurement results of the device is $\pm 8 \%$. The measurements were made by a cone with a cross-sectional dimension of $2 \mathrm{~cm}^{2}$. Within each measurement point, the mechanical impedance of the soil was measured in a single replication.

To measure the electrical conductivity of the soil in situ, the sensor HI 76305 was used (Hanna Instruments, Woonsocket, R.I.). This sensor works in conjunction with a portable device HI 993310 . The tester estimates the total electrical conductivity of the soil, ie. combined conductivity of soil air, water and particles. The results of measurements taken by the device are presented in units of saturation of the soil solution with salts as $\mathrm{g} / \mathrm{l}$. Comparison of measurement results of HI 76305 with laboratory data allowing us to estimate the conversion factor of units as 1 $\mathrm{dS} / \mathrm{m}=155 \mathrm{mg} / \mathrm{l}$ (PENNISI and VAN IERSEL, 2002). 
Soil temperature was measured from 1 to 2 pm by digital thermometers WT-1 (PJSC 'Steklopribor' (http:// bit.steklopribor.com), to $0.1{ }^{\circ} \mathrm{C}$ accuracy) at a depth of 5-7 $\mathrm{cm}$. Temperature measurements were made in triplicate at each test point.

The aggregate structure was evaluated by Savinov's dry sieving method (VADUNINA and KorChaGina, 1986). The percentage content of the following fractions was established: $<0.25,0.25-0.5,0.5-1,1-2,2-3,3-5,5-7$, $7-10,>10 \mathrm{~mm}$, and plant roots. The soil density was estimated by the Kachinskiy method, soil moisture by the weight method (VADUNINA and KorCHAGINA, 1986).

\section{Statistical analysis}

The results of measuring the environmental properties were subjected to principal components analysis to reduce the influence of the spatial characteristic and prevent multicollinearity of predictors. The number of significant principal components was calculated on the basis of the Horn procedure (HoRN, 1965). The operation was completed using paran package (DinNo, 2012). The principal components analysis was carried out separately for edaphic properties and for phytoindication values. Thus, two sets of predictors of environmental properties were formed: edaphic and vegetational.

The species matrix of soil animals was standardized using Hellinger distance before the analysis. Further, the linear trend of the macrofauna community was removed. A spatial structure can be modeled by a set of independent spatial patterns (PCNM - Principal Coordinates of Neighbor Matrices, or later name MEMs - Moran's eigenvector maps). The spatial variables were calculated after spectral decomposition of the truncated distance matrix between the sampling points. The order of these variables corresponds to a sequence of variations from broad-scale to medium- and fine-scale. The PCNM approach allows us to receive $n-1$ spatial variable with positive and negative eigenvalues. For the analysis, only variables with positive eigenvalues were selected as predictors. Forward selection of environment variables or spatial variables was performed using the function forward.sel in the Packfor package (DrAY et al., 2016). The forward selection procedure allows us to select variables with a statistically significant ( $p<0.05$ after 999 permutations) contribution to the explained variation of the soil animal community (BlANCHET et al., 2008). Only the selected variables were used for further analysis.

The variation partitions of the community data (BoRCARD et al., 1992) was performed to quantify the proportions of variation in the composition of the community, which are explained by a set of environmental variables or spatial variables. Adjusted values $R^{2}$ allowed us to calculate the pure environmental component, the pure spatial component and mixed spatial and environmental components of the community variation.

Further, redundancy analysis (RDA) and linear regression analysis were used to determine the nature of the dependence of the spatially structured variation of the macrofauna community on edaphic and vegetational factors of the environment on broad-scale, medium-scale and fine-scale spatial levels.

Statistical calculations were performed using the Statistica 7.0 program and the Project $\mathrm{R}$ ' $\mathrm{R}$ software shell: A Language and Environment for Statistical Computing' ( $R$ Core Team, 2017). Estimation of confidence intervals and the standard deviation of the number of soil animals were produced using a bootstrap approach and implemented by means of the bootES package (KIRBY and GERLANC, 2013).

\section{Results}

During manual sifting of the soil samples from the polygon, 34 species of soil animals were found. The density of the soil macrofauna of the polygon was $178.4 \pm 26.9$ ind. $\mathrm{m}^{-2}$ (Table 1). Comparison with other biotopes within the Dnipro river arena indicates the rather extreme conditions for soil animals in the soil of the flood plain, since the species richness and abundance in this biotope is at a low level. Thus, data collection using the same methodology has shown that the soil macrofauna community of the broadleaf forests in the Dnipro river arena is represented by 45 species with an abundance of 305.37 ind. $\mathrm{m}^{-2}$ (ZHUKov et al., 2015), meadows -47 species with an abundance of 254.63 ind. $\mathrm{m}^{-2}$, bogs -59 species with an abundance of 197.49 ind. $\mathrm{m}^{-2}$ (unpublished data), sandy steppe - 29 species with abundance of $68.86 \pm 14.62$ ind. $\mathrm{m}^{-2}$ (ZHukov et al., 2016). The extreme habitat manifests itself in the low level of abundance and species diversity within the community, which is the result of the action of a limiting factor (or factors).

The dominant group was earthworms (Lumbricidae), which averaged $38.8 \%$ of the total community abundance. Earthworms were represented by four species: the litter dwelling earthworm Dendrobaena octaedra, two endogeic species Aporrectodea trapezoides and Aporrectodea rosea and one anecic species Octodrilus transpadanus. Taxonomically close to earthworms, Enchytraeidae were present, the average abundance of which was $5.94 \pm 1.28$ ind. $\mathrm{m}^{-2}$.

Spiders accounted for $1.5 \%$ of the total abundance of the macrofauna complex. More diverse and abundant was another group of carnivorous invertebrates - Chilopoda. They made up $6.1 \%$ of the total community abundance. This group was represented by four species, of which two species are litter specialists (Lithobius curtipes, Lithobius aeruginosus), one species is endogeic (Geophilus proximus) and one species is anecic (Pachymerium ferrugineum). The soil-dwelling Chilopoda are more abundant than their litter-dwelling relatives, which may be explained by the fact that sandy soil in the flood plain is considerably drained and dry. Soil and litter moisture is an important factor affecting the soil animals (BRYGADYRENKO, 2015, 2016). The ratio between the litter-dwelling Lithobiomor- 
Table 1. Species composition and abundance of soil macrofauna community (ind. $\mathrm{m}^{-2}$ )

\begin{tabular}{|c|c|c|c|}
\hline \multirow{2}{*}{ Taxons } & \multirow{2}{*}{ Mean \pm st. error } & \multicolumn{2}{|c|}{ Confidence interval } \\
\hline & & $-95 \%$ & $+95 \%$ \\
\hline \multicolumn{4}{|l|}{ Haplotaxida } \\
\hline Aporrectodea caliginosa trapezoides (Duges, 1828) & $10.36 \pm 1.82$ & 7.31 & 14.57 \\
\hline Aporrectodea rosea rosea (Savigny, 1826) & $54.55 \pm 4.23$ & 46.63 & 62.93 \\
\hline Dendrobaena octaedra (Savigny, 1826) & $1.22 \pm 0.47$ & 0.46 & 2.29 \\
\hline Octodrilus transpadanus (Rosa, 1884) & $3.05 \pm 0.72$ & 1.68 & 4.57 \\
\hline \multicolumn{4}{|l|}{ Tubificida } \\
\hline Enchytraeus sp. & $5.94 \pm 1.28$ & 3.66 & 8.69 \\
\hline \multicolumn{4}{|l|}{ Arachnida } \\
\hline Lycosidae sp. & $2.59 \pm 0.62$ & 1.37 & 3.81 \\
\hline \multicolumn{4}{|l|}{ Geophilomorpha } \\
\hline Geophilus proximus (C.L.Koch, 1847 & $5.64 \pm 1.11$ & 3.66 & 8.08 \\
\hline Pachymerium ferrugineum (C.L. Koch, 1835) & $3.50 \pm 0.85$ & 1.98 & 5.18 \\
\hline Lithobius (Monotarsobius) aeruginosus L. Koch 1862) & $0.30 \pm 0.21$ & 0.00 & 0.76 \\
\hline Lithobius (Monotarsobius) curtipes (C.L. Koch, 1847) & $1.52 \pm 0.54$ & 0.61 & 2.74 \\
\hline \multicolumn{4}{|l|}{ Julida } \\
\hline Megaphyllum rossicum (Timotheew, 1897) & $14.78 \pm 1.71$ & 11.58 & 18.44 \\
\hline Megaphyllum sjaelandicum (Meinert, 1868) & $17.07 \pm 1.95$ & 13.56 & 21.03 \\
\hline \multicolumn{4}{|l|}{ Polydesmida } \\
\hline Polydesmus inconstans (Latzel, 1884) & $2.59 \pm 0.75$ & 1.22 & 4.27 \\
\hline \multicolumn{4}{|l|}{ Coleoptera } \\
\hline Amara sp. (larv.) & $0.15 \pm 0.15$ & 0.00 & 0.46 \\
\hline Chrysolina (Fastuolina) fastuosa (Scopoli, 1763) (larv.) & $0.30 \pm 0.31$ & 0.00 & 0.91 \\
\hline Otiorhynchus (Cryphiphorus) ligustici (Linnaeus, 1758) (larv.) & $1.83 \pm 0.50$ & 0.91 & 2.74 \\
\hline Athous (Athous) haemorrhoidalis (Fabricius, 1801) (larv.) & $1.22 \pm 0.42$ & 0.46 & 2.03 \\
\hline Prosternon tessellatum (Linnaeus 1758) (larv.) & $0.76 \pm 0.33$ & 0.15 & 1.52 \\
\hline Agriotes (Agriotes) lineatus (Linnaeus 1767) (larv.) & $0.46 \pm 0.26$ & 0.00 & 1.07 \\
\hline Cardiophorus rufipes (Goeze, 1777) (larv.) & $0.46 \pm 0.26$ & 0.00 & 1.07 \\
\hline Platydracus (Platydracus) fulvipes (Scopoli, 1763) (larv.) & $0.61 \pm 0.43$ & 0.00 & 1.52 \\
\hline Isomira murina (Linnaeus, 1758) (larv.) & $0.15 \pm 0.15$ & 0.00 & 0.46 \\
\hline Amphimallon solstitiale (Linnaeus, 1758) (larv.) & $0.15 \pm 0.15$ & 0.00 & 0.46 \\
\hline Melolontha melolontha (Linnaeus, 1758) (larv.) & $2.29 \pm 0.53$ & 1.22 & 3.35 \\
\hline Serica brunnea (Linnaeus, 1758) (larv.) & $1.83 \pm 0.49$ & 0.91 & 2.76 \\
\hline \multicolumn{4}{|l|}{ Dermaptera } \\
\hline Forficula auricularia Linnaeus, 1758 & $0.76 \pm 0.34$ & 0.15 & 1.52 \\
\hline \multicolumn{4}{|l|}{ Diptera } \\
\hline Thereva nobilitata (Fabricius, 1775) (larv.) & $2.44 \pm 0.78$ & 1.22 & 4.27 \\
\hline Cyrtopogon lateralis (Fallen, 1814) (larv.) & $0.61 \pm 0.31$ & 0.15 & 1.22 \\
\hline Rhagio scolopaceus (Linnaeus, 1758) (larv.) & $1.83 \pm 0.51$ & 0.91 & 2.90 \\
\hline Tabanus bromius (Linnaeus, 1758) (larv.) & $0.91 \pm 0.36$ & 0.30 & 1.68 \\
\hline Lepidoptera & & & \\
\hline
\end{tabular}


Table 1. Species composition and abundance of soil macrofauna community (ind. $\mathrm{m}^{-2}$ ) - continued

\begin{tabular}{|c|c|c|c|}
\hline Agrotis clavis (Hufnagel, 1766) (larv.) & $37.33 \pm 3.53$ & 31.09 & 44.80 \\
\hline \multicolumn{4}{|l|}{ Isopoda } \\
\hline Trachelipus rathkii (Brandt, 1833) & $0.76 \pm 0.41$ & 0.15 & 1.83 \\
\hline \multicolumn{4}{|l|}{ Pulmonata } \\
\hline Zonitoides (Zonitoides) nitidus (O.F. Muller, 1774) & $0.30 \pm 0.30$ & 0.00 & 0.91 \\
\hline Succinella oblonga (Draparnaud, 1801) & $0.15 \pm 0.16$ & 0.00 & 0.46 \\
\hline
\end{tabular}

pha and soil-dwelling Geophilomorpha has been proposed as an indicator for the soil humidity level (GILYAROv and Folkmanova, 1957). The ratio between the epigeic and endogeic earthworms resembles the ratio between the litter and soil species of the Chilopoda. That is why the dry soil condition may lead to the dominance of soil-dwelling as compared to the litter-dwelling animals

Saprotrophic Diplopoda made up $19.3 \%$ of the total community abundance and they were represented by three species which are primary litter decomposers. Other primary decomposers of the litter were woodlice Trachelipus rathkii and molluscs Zonitoides nitidus and Succinella oblonga. Their abundance within the community was extremely low.

The insect complex was diverse, represented by 18 species. The insect abundance was $30.3 \%$ of the total abundance of the macrofauna community. Representatives of the groups Coleoptera, Diptera and Lepidoptera in the soil from the polygon were at the larval stage. Invertebrates at the larval stages made up $29.9 \%$ of the entire soil animal community. Larvae (juvenile forms) were found only among the insects, among which this age stage made up $98.6 \%$.

The parameters of the habitat of the soil animals are represented by 66 variables: 35 edaphic indicators and 31 indicators of vegetation cover. The large number of variables and their mutual correlation makes it reasonable to use principal components analysis as a procedure for dimension reduction. It should be noted that the new variables obtained are orthogonal, ie. statistically independent (Table 2).

As a result of the analysis of edaphic characteristics, nine principal components, whose eigenvalues exceed 1 , were identified. Using the Horn procedures (HoRN, 1965) we found that these principal components are statistically significant. The 9 principal components explain $78.5 \%$ of the overall variability of the edaphic properties. Principal component 1 can be interpreted meaningfully as variation of soil mechanical impedance at a depth of 35-100 cm. Principal component 2 is the variation in mechanical impedance at a depth of $0-40 \mathrm{~cm}$, as well as the electrical conductivity of the soil, litter thickness and topsoil temperature. Principal component 3 reflects the variation of the electrical conductivity of the soil, litter thickness and soil temperature, as well as features of aggregate composition. This component is sensitive to the opposite dynamics of aggregate fractions ranging in size from 0.5 to $10 \mathrm{~mm}$ and more in relation to the content of fractions of $0.5-3$ mm. Principal component 4 reflects the combined variation of the density and mechanical impedance of the soil against the background of a change in the content of fractions $>10 \mathrm{~mm}$ and $5-7 \mathrm{~mm}$, as well as the roots of plants. Principal component 5 reflects the mutually opposite dynamic of content change of the aggregate fractions of 2-7 $\mathrm{mm}$, on the one hand, and $<0.25-2 \mathrm{~mm}$, on the other. Also this component is connected with the variation in litter thickness, electrical conductivity and mechanical impedance of the soil at certain depths. Principal component 6 is sensitive to soil variation mainly in the middle part of the measured range $(20-65 \mathrm{~cm})$. Principal component 7 is sensitive to varying mechanical impedance of the soil at a depth of 0-10 and 45-70 $\mathrm{cm}$, and principal component 8 is sensitive to the variation of mechanical impedance at a depth of $65-80 \mathrm{~cm}$, while principal component 9 is sensitive to the variation of mechanical impedance at a depth of 50-75 cm. Also, principal component 9 reflects the multidirectional dynamics of variation of aggregate fraction content with dimensions of 3-7 mm, on the one hand, and $0.5-3 \mathrm{~mm}$, on the other.

Analysis of the characteristics of vegetation made it possible to extract 7 principal components whose eigenvalues exceed 1 (Table 3 ). Using the Horn procedures (HoRN, 1965) we found that these principal components are statistically significant. They together explain $78.0 \%$ of the overall variability of the vegetation indices. The principal components reflect the complex nature of the relationship between indicators in a way that creates some difficulty in interpreting the principal components in terms of primary environmental factors. Thus, principal component 1 is predominantly marked with an Ellenberg moisture index. However, this component is also sensitive to the variation of almost all values of the Didukh scale (with the exception of the nitrogen supply scale), Belgard indices and Ellenberg scales. The most reasonable interpretation of the principal component 1 could be a correlation between the forest vegetation layer and the herbaceous layer. Principal component 2 is also sensitive to the ratio of the forest and herbaceous layers, but its main trend is the acidity of the soil, which manifests itself both on the Ellenberg and Didukh scales. Principal component 3 indicates ceonomorphic variability of vegetation within the studied site. This component contrasts the variability of the role of the silvants (Sil) in the community of the role of pratants (Pr), ruderants $(\mathrm{Ru})$, and stepants $(\mathrm{St})$. 
Table 2. Descriptive statistics and principal components analysis of the edaphic properties $(\mathrm{N}=105$, significant correlation coefficients with $p<0.05$ are presented only)

\begin{tabular}{|c|c|c|c|c|c|c|c|c|c|c|}
\hline \multirow{2}{*}{\multicolumn{2}{|c|}{ Properties (mean \pm st. error) }} & \multicolumn{9}{|c|}{ Principal component } \\
\hline & & 1 & 2 & 3 & 4 & 5 & 6 & 7 & 8 & 9 \\
\hline \multicolumn{11}{|c|}{ Litter depth and soil temperature } \\
\hline Litter $(\mathrm{cm})$ & $2.04 \pm 0.14$ & - & 0.15 & 0.34 & 0.35 & -0.43 & - & 0.48 & - & - \\
\hline Temperature $\left({ }^{\circ} \mathrm{C}\right)$ & $13.58 \pm 0.04$ & - & -0.15 & -0.42 & - & - & - & - & 0.75 & - \\
\hline \multicolumn{11}{|c|}{ Soil mechanical impedance at depth (MPa) } \\
\hline $0-5 \mathrm{~cm}$ & $0.96 \pm 0.03$ & - & 0.47 & - & - & - & 0.31 & -0.21 & - & - \\
\hline $5-10 \mathrm{~cm}$ & $1.17 \pm 0.03$ & - & 0.80 & - & - & - & - & -0.24 & - & - \\
\hline $10-15 \mathrm{~cm}$ & $1.54 \pm 0.05$ & - & 0.90 & - & - & - & - & - & - & - \\
\hline $15-20 \mathrm{~cm}$ & $2.04 \pm 0.06$ & - & 0.89 & - & - & - & - & - & - & - \\
\hline $20-25 \mathrm{~cm}$ & $2.54 \pm 0.06$ & - & 0.78 & - & - & - & 0.39 & - & - & - \\
\hline $25-30 \mathrm{~cm}$ & $3.07 \pm 0.08$ & - & 0.55 & - & - & - & 0.65 & 0.31 & - & - \\
\hline $30-35 \mathrm{~cm}$ & $3.47 \pm 0.10$ & - & 0.38 & - & - & - & 0.82 & - & - & - \\
\hline $35-40 \mathrm{~cm}$ & $3.74 \pm 0.12$ & 0.27 & 0.25 & - & - & - & 0.77 & - & - & - \\
\hline $40-45 \mathrm{~cm}$ & $4.33 \pm 0.13$ & 0.30 & - & - & - & - & 0.85 & - & - & - \\
\hline $45-50 \mathrm{~cm}$ & $4.84 \pm 0.13$ & 0.39 & - & - & - & - & 0.76 & -0.29 & - & - \\
\hline $50-55 \mathrm{~cm}$ & $5.36 \pm 0.14$ & 0.52 & - & - & - & - & 0.59 & -0.35 & - & 0.25 \\
\hline $55-60 \mathrm{~cm}$ & $5.91 \pm 0.14$ & 0.60 & - & - & - & - & 0.40 & -0.40 & - & 0.33 \\
\hline $60-65 \mathrm{~cm}$ & $6.24 \pm 0.16$ & 0.62 & - & - & - & - & 0.31 & -0.38 & - & 0.34 \\
\hline $65-70 \mathrm{~cm}$ & $6.56 \pm 0.14$ & 0.68 & - & - & - & - & - & -0.27 & 0.38 & 0.29 \\
\hline $70-75 \mathrm{~cm}$ & $6.73 \pm 0.16$ & 0.68 & - & - & - & - & - & - & 0.38 & 0.26 \\
\hline $75-80 \mathrm{~cm}$ & $6.71 \pm 0.16$ & 0.74 & - & - & - & - & - & - & 0.29 & - \\
\hline $80-85 \mathrm{~cm}$ & $6.54 \pm 0.16$ & 0.81 & - & - & - & 0.23 & 0.27 & - & - & - \\
\hline $85-90 \mathrm{~cm}$ & $6.59 \pm 0.16$ & 0.84 & - & - & - & 0.23 & - & - & - & - \\
\hline $90-95 \mathrm{~cm}$ & $6.53 \pm 0.18$ & 0.83 & - & - & - & - & 0.24 & - & - & - \\
\hline $95-100 \mathrm{~cm}$ & $6.70 \pm 0.19$ & 0.80 & - & - & - & - & 0.22 & - & -0.24 & - \\
\hline \multicolumn{11}{|c|}{ Other edaphic indicators } \\
\hline Humidity (\%) & $16.46 \pm 0.86$ & - & - & - & 0.75 & - & - & - & 0.36 & - \\
\hline Density $\left(\mathrm{g} \mathrm{cm}^{-3}\right)$ & $0.89 \pm 0.02$ & - & - & - & -0.89 & - & - & - & - & - \\
\hline $\mathrm{EC}, \mathrm{dSm}\left(\mathrm{m}^{-1}\right)$ & $0.13 \pm 0.01$ & - & 0.50 & 0.21 & - & -0.36 & - & 0.33 & -0.22 & - \\
\hline \multicolumn{11}{|c|}{ Aggregate fractions $(\mathrm{mm})$ and roots of plants $(\%)$} \\
\hline$>10$ & $12.91 \pm 0.71$ & - & - & 0.78 & -0.24 & - & - & - & - & - \\
\hline $7-10$ & $7.28 \pm 0.28$ & - & - & 0.76 & - & -0.27 & - & - & -0.27 & - \\
\hline $5-7$ & $9.81 \pm 0.35$ & - & - & 0.74 & 0.20 & -0.24 & - & - & - & -0.22 \\
\hline $3-5$ & $23.13 \pm 0.85$ & - & - & 0.20 & - & -0.35 & - & - & - & -0.82 \\
\hline $2-3$ & $27.68 \pm 0.82$ & - & -0.24 & -0.75 & - & -0.29 & - & -0.22 & - & 0.27 \\
\hline $1-2$ & $13.96 \pm 0.86$ & - & - & -0.59 & - & 0.42 & - & 0.32 & 0.20 & 0.42 \\
\hline $0.5-1$ & $1.37 \pm 0.12$ & - & - & -0.28 & - & 0.46 & - & - & 0.29 & 0.33 \\
\hline $0.25-0.5$ & $2.29 \pm 0.29$ & - & - & - & - & 0.87 & - & - & - & - \\
\hline$<0.25$ & $0.61 \pm 0.09$ & - & - & - & - & 0.85 & - & - & - & - \\
\hline Roots & $0.95 \pm 0.08$ & - & - & - & 0.44 & - & - & -0.69 & - & - \\
\hline \multicolumn{2}{|c|}{$\%$ variance } & 23.75 & 17.19 & 10.27 & 6.17 & 5.66 & 4.58 & 4.16 & 3.84 & 2.92 \\
\hline \multicolumn{2}{|c|}{$\%$ of the community variance explained } & 1.66 & 1.04 & 1.45 & 0.42 & 1.63 & 0.53 & 1.12 & 1.37 & 0.81 \\
\hline \multicolumn{2}{|c|}{ Community Sensitivity } & 0.70 & 0.60 & 1.41 & 0.68 & 2.87 & 1.15 & 2.68 & 3.56 & 2.77 \\
\hline \multicolumn{2}{|c|}{$\begin{array}{l}\text { A reliable predictor }(+) \\
\text { of the structure of the community }\end{array}$} & + & + & + & + & + & - & + & + & - \\
\hline
\end{tabular}


Principal component 4 is sensitive to the role in the community of shrubs, as well as variability of carbonate content and aeration of the soil. Principal component 5 is interpreted as the level of nitrogen nutrition of the soil. Principal component 6 reflects the inverse relationship between the paludants (according to Belgard paludants are the swamp dwellers) and ruderants, which occurs against the background of the variability of water regime, nutrient status and humidity on the Belgard scale and the variation in the role of geophytes in the community. Principal component 7 is marked with the indices of humidity according to Didukh and according to Ellenberg, which allows it to be interpreted as a measure of variability of humidity.

The redundancy analysis indicates that the edaphic factors of the environment, presented with the help of principal components, explain $10.9 \%$ of the variability of the macrofauna community (Table 2). The forward selection procedure made it possible to find that the statistically significant influence on the structure of the community is exerted by the principal components $1,2,3,4,5,7$ and 8 . These principal components explain $9.2 \%$ of the variability of the community $(F=2.51, \mathrm{p}<0.001)$. With the help of the redundancy analysis, it is shown that the indices of the vegetation properties presented in the form of principal components, explain $7.8 \%$ of the variability of the macrofauna community (Table 3 ). The forward selection procedure made it possible to figure out that a statistically significant influence on the structure of the community is exerted by the principal components $1,3,4,5,6,7$. These principal components explain $6.9 \%$ of the variability of the community $(F=2.29, \mathrm{p}<0.001)$.

The order of the principal components reflects their relative contribution to the variation of the indicative space of environmental properties. The results obtained show that the contribution of the principal components to the variation of the soil animals community does not correspond to the level of variation of the most important component. This feature reflects the sensitivity of the mac- rofauna community to the action of the principal components. Sensitivity may be estimated as the ratio between the unique contribution of the principal component to the variation in the macrofauna community and the proportion of variance of the indicative space, which is explained by this principal component. For this indicator, among the edaphic characteristics, the macrofauna community is most sensitive to the principal component 8 (sensitivity 3.56), and least to principal components 1, 2 and 4. Among indicators of vegetation, the most significant influence on the soil macrofauna is exerted by the principal components 4,6 and 7 .

There are 72 PCNM-spatial variables, which together explain $42.6 \%$ of the macrofauna community variability. The forward selection procedure allowed us to select 30 variables, which explain $28.8 \%$ of the variability of the community $(F=2.68, \mathrm{p}<0.001)$.

Taking into account a combination of the parameters of the environment and spatial variables, the variation fractioning of the macrofauna community is shown in Fig. 2. After the extraction of the conditional effect of vegetational factors and spatial variables, soil factors of the environment explain $7.2 \%$ of the community variability $(F=1.68, \mathrm{p}<0.001)$. After the extraction of the conditional effect of edaphic factors and spatial variables, vegetation factors explain $3.2 \%$ of the variability of the community $(F=1.61, \mathrm{p}<0.001)$. The combined effect of spatial and edaphic factors explains $5.5 \%$ of the variability of the macrofauna community, and the combined influence of spatial and vegetation factors explains $4.1 \%$. The role of the interaction of edaphic properties and vegetation is extremely small $(0.3 \%)$.

The spatial and the combined environmental and spatial effects were divided into three components: Broadscale (PCNM-variables 2, 4, 5, 6, 7, 8, 9, 10, 12, 13), medium-scale (PCNM-variables 15, 16, 17, 18, 20, 24, 26, 27, 30, 31) and fine-scale (PCNM-variables 32, 33, 39, $43,46,48,49,50,52,54)$. The broad-scale component
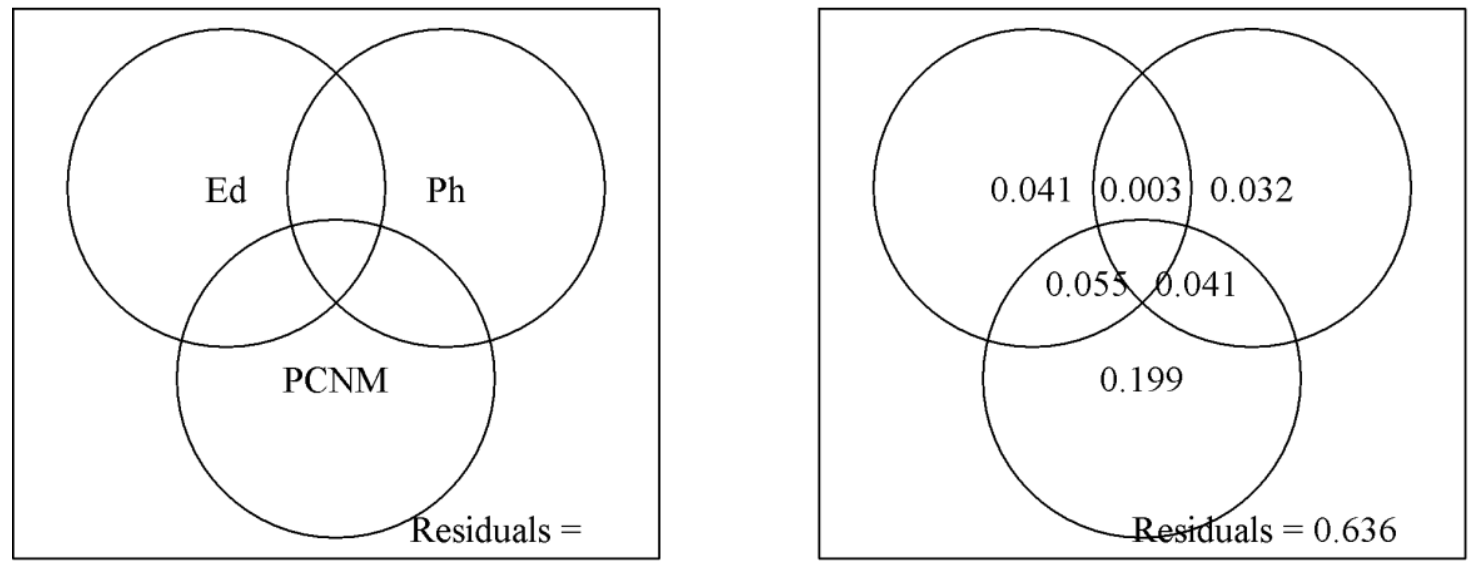

Fig. 2. Fractional variation of macrofauna community matrix by edaphic and vegetation explanatory matrices. On the left is the scheme for placing factors of variation, on the right are estimates of the explained variation. Ed are soil factors; Ph are vegetational environmental factors; PCNM are spatial factors. 
is characterized by periodicity of spatial variation with a wavelength of $24.0-44.5 \mathrm{~m}$, medium-scale $-11.1-20 \mathrm{~m}$, fine-scale $-6.6-11.0 \mathrm{~m}$.

The broad-scale component of the spatial variability of the community explains $10.8 \%$ of variation $(F=2.26$, $p=0.001)$, medium-scale component explains $7.7 \%(F=$ $1.86, p=0.001)$, fine-scale component explains $6.4 \%(F=$ $1.71, p=0.001)$.

Spatial variation of the canonical axes, which are obtained for different spatial scales of components of the soil animal community variation, is shown in the Figure 3.

The markers of the axes are 18 species of soil invertebrates (Table 4). Among them, 1 species marks 6 axes ( $A$. trapezoides), 3 species mark 5 axes (A. rosea, M. rossicum, M. sjaelandicum), 2 species mark 4 axes (A. clavis, T. nobilitata), 4 species mark 3 axes (D. octaedra, Enchytraeus sp., P. ferrugineum, P. inconstans), 4 species mark 2 axes (G. proximus, M. melolontha, O. transpadanus, S. brunnea) and 4 species are marked on one axis (A. haemorrhoidalis, A. lineatus, C. lateralis, O. ligustici).

It is stated that the regression model of the effect of environmental parameters on the spatial variation components of the macrofauna community can account for $8-42 \%$ of their variability. At the same time, the broad- scale component plays the largest role among environmental factors $(14-42 \%)$. This role is somewhat lower for the medium-scale component (8-26\%) and the least explanatory power of the regression model is typical for the finescale component (8-16\%). Statistical significance of one regression model for a medium-scale component and two for a fine-scale component is above the critical level $\mathrm{p}=$ 0.05 . Thus, it can be recognized that the medium-scale axis RDA3 and fine-scale axes RDA2 and RDA3 mainly carry information about the spatial variation of the community. Spatial components of the community variation carry information on both the spatial and the environmental aspects of the macrofauna community response. Regression analysis made it possible to identify those principal components, which are characterized by statistically significant regression coefficients (Table 5).

\section{Discussion}

With respect to the impact on the structure of the community, the role of environmental factors is different and does not correlate with its relative variability. The forward selection procedure made it possible to establish that, out of 9 edaphic principal components, there are 7 reliable

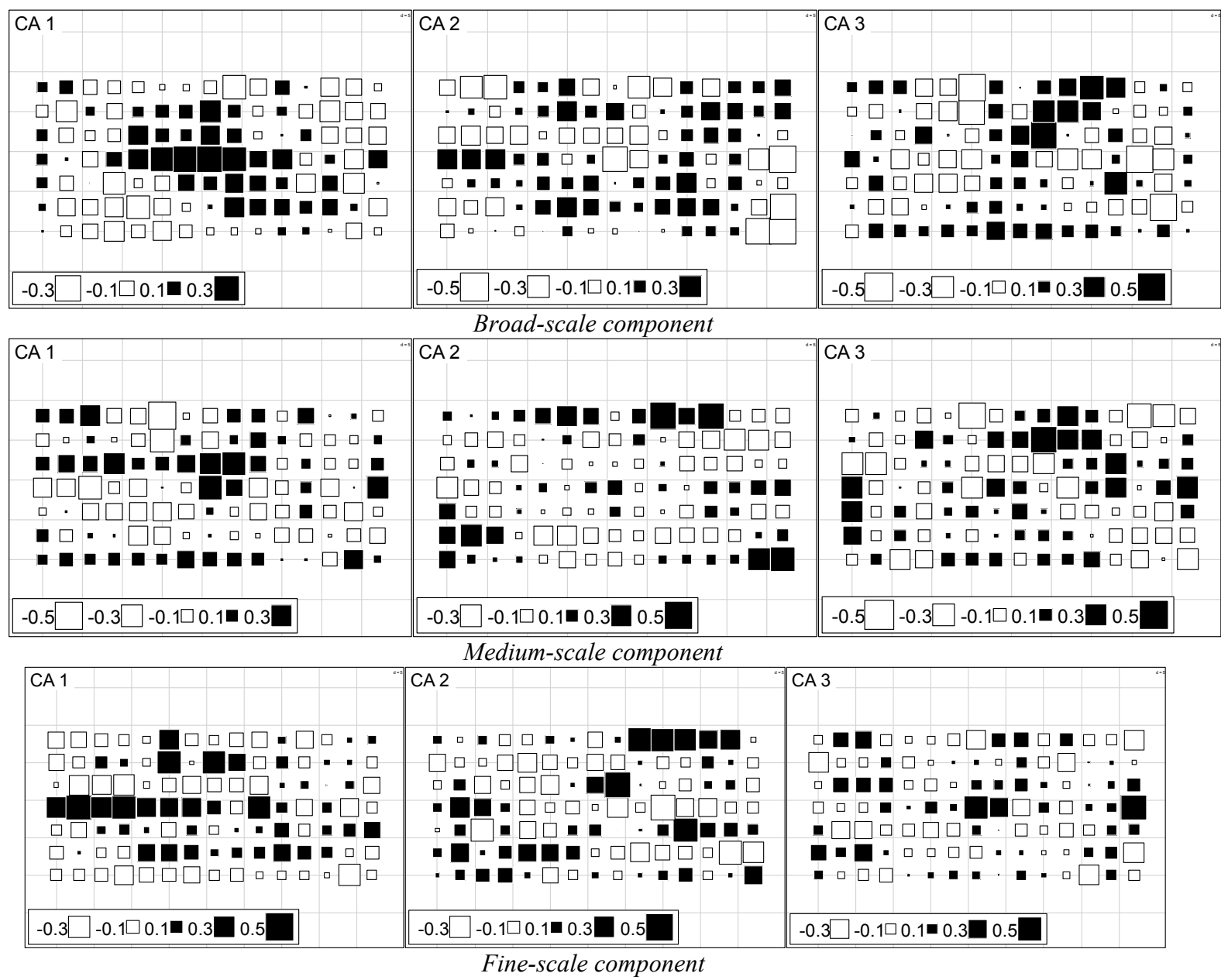

Fig. 3. Spatial variation of the canonical axes, explaining different scale levels of the spatial dependence of soil macrofauna. 
Table 3. Descriptive statistics and analysis of the principal components of vegetation indicators $(\mathrm{N}=105$, significant correlation coefficients with $p<0.05$ are presented only)

\begin{tabular}{|c|c|c|c|c|c|c|c|c|}
\hline \multirow{2}{*}{\multicolumn{2}{|c|}{ Indicators }} & \multicolumn{7}{|c|}{ Principal component } \\
\hline & & 1 & 2 & 3 & 4 & 5 & 6 & 7 \\
\hline \multicolumn{9}{|c|}{ Didukh scales } \\
\hline $\mathrm{Hd}$ & $12.41 \pm 0.16$ & -0.21 & - & - & 0.23 & - & - & -0.77 \\
\hline $\mathrm{ffl}$ & $5.50 \pm 0.12$ & 0.39 & -0.35 & - & 0.42 & -0.43 & -0.20 & 0.30 \\
\hline $\mathrm{Rc}$ & $6.75 \pm 0.07$ & 0.43 & 0.62 & - & - & - & - & 0.47 \\
\hline $\mathrm{S} 1$ & $4.59 \pm 0.18$ & 0.67 & - & - & 0.36 & - & - & 0.20 \\
\hline $\mathrm{Ca}$ & $4.63 \pm 0.19$ & 0.34 & 0.27 & - & 0.70 & - & - & - \\
\hline $\mathrm{Nt}$ & $12.73 \pm 0.13$ & - & 0.26 & - & -0.31 & 0.72 & - & - \\
\hline $\mathrm{Ae}$ & $5.20 \pm 0.11$ & 0.46 & 0.33 & - & 0.72 & - & - & - \\
\hline $\mathrm{Tm}$ & $9.60 \pm 0.07$ & 0.35 & -0.26 & - & 0.28 & -0.55 & - & 0.47 \\
\hline $\mathrm{Om}$ & $13.81 \pm 0.14$ & 0.59 & -0.27 & - & 0.20 & 0.47 & - & - \\
\hline $\mathrm{Kn}$ & $8.88 \pm 0.17$ & -0.36 & - & - & -0.58 & - & - & -0.59 \\
\hline $\mathrm{Cr}$ & $8.43 \pm 0.06$ & 0.71 & - & - & - & -0.32 & - & 0.35 \\
\hline $\mathrm{Lc}$ & $4.30 \pm 0.15$ & 0.57 & -0.29 & - & 0.56 & - & - & 0.35 \\
\hline \multicolumn{9}{|c|}{ Indices based on Belgard's ecomorphs } \\
\hline Troph_B & $2.41 \pm 0.02$ & - & -0.85 & - & - & - & 0.21 & - \\
\hline Hygr_B & $3.14 \pm 0.03$ & - & 0.92 & - & - & - & - & - \\
\hline Hel_B & $2.92 \pm 0.01$ & -0.42 & - & - & - & -0.59 & 0.41 & - \\
\hline \multicolumn{9}{|c|}{ Ellenberg's indicator values } \\
\hline $\mathrm{L}$ & $5.86 \pm 0.04$ & 0.44 & -0.60 & - & 0.54 & - & - & - \\
\hline $\mathrm{T}$ & $6.10 \pm 0.01$ & - & -0.28 & - & 0.28 & -0.25 & - & 0.58 \\
\hline $\mathrm{K}$ & $5.34 \pm 0.01$ & -0.30 & -0.83 & - & -0.19 & - & - & - \\
\hline $\mathrm{F}$ & $6.24 \pm 0.05$ & -0.77 & - & - & -0.34 & - & - & -0.42 \\
\hline $\mathrm{R}$ & $6.10 \pm 0.03$ & - & 0.89 & - & - & 0.33 & - & - \\
\hline $\mathrm{N}$ & $6.89 \pm 0.04$ & - & 0.57 & - & 0.28 & 0.64 & - & - \\
\hline \multicolumn{9}{|c|}{ Coenomorphs by Belgard } \\
\hline Pal & $0.01 \pm 0.00$ & - & - & 0.23 & - & - & 0.58 & - \\
\hline $\operatorname{Pr}$ & $0.02 \pm 0.00$ & - & - & -0.72 & - & - & - & - \\
\hline $\mathrm{Ru}$ & $0.03 \pm 0.00$ & 0.38 & 0.28 & -0.21 & - & -0.26 & -0.42 & - \\
\hline Sil & $0.91 \pm 0.01$ & - & - & 0.93 & - & - & - & - \\
\hline St & $0.03 \pm 0.01$ & - & - & -0.75 & - & - & - & 0.23 \\
\hline \multicolumn{9}{|c|}{ Raunkier's life forms } \\
\hline $\mathrm{Ph}$ & $60.57 \pm 2.19$ & -0.62 & -0.35 & - & -0.55 & - & - & -0.35 \\
\hline $\mathrm{nPh}$ & $10.25 \pm 0.93$ & - & - & - & 0.94 & - & - & - \\
\hline $\mathrm{HKr}$ & $18.42 \pm 1.16$ & 0.89 & 0.29 & - & - & - & - & - \\
\hline $\mathrm{T}$ & $9.33 \pm 0.89$ & 0.33 & 0.30 & - & - & - & - & 0.73 \\
\hline $\mathrm{G}$ & $0.014 \pm 0.003$ & - & 0.23 & - & 0.35 & - & -0.74 & - \\
\hline \multicolumn{2}{|c|}{$\%$ of total variance } & 29.56 & 19.53 & 8.78 & 6.49 & 5.55 & 4.31 & 3.82 \\
\hline \multicolumn{2}{|c|}{$\begin{array}{l}\% \text { of the community variance } \\
\text { explained }\end{array}$} & 0.96 & 0.76 & 0.62 & 1.48 & 0.91 & 1.64 & 0.97 \\
\hline \multicolumn{2}{|c|}{ Community sensitivity } & 0.44 & 0.53 & 0.96 & 3.11 & 2.23 & 5.18 & 3.46 \\
\hline \multicolumn{2}{|c|}{$\begin{array}{l}\text { A reliable predictor of the } \\
\text { community structure }\end{array}$} & + & - & + & + & + & + & + \\
\hline
\end{tabular}


Table 4. Species with the largest absolute value of the canonical axes

\begin{tabular}{|c|c|c|c|c|c|c|c|c|}
\hline \multicolumn{3}{|c|}{ Broad-scale component } & \multicolumn{3}{|c|}{ Medium-scale component } & \multicolumn{3}{|c|}{ Fine-scale component } \\
\hline RDA1 & RDA2 & RDA3 & RDA1 & RDA2 & RDA3 & RDA1 & RDA2 & RDA3 \\
\hline \multicolumn{9}{|c|}{ Three species with the largest value of the canonical axes } \\
\hline $\begin{array}{l}\text { M. rossi- } \\
\text { cum }\end{array}$ & $\begin{array}{l}\text { M. melo- } \\
\text { lontha }\end{array}$ & $\begin{array}{l}\text { M. rossi- } \\
\text { cum }\end{array}$ & A. lineatus & $\begin{array}{c}\text { T. nobili- } \\
\text { tata }\end{array}$ & $\begin{array}{l}P . \text { ferrugi- } \\
\text { neum }\end{array}$ & S. brunnea & $\begin{array}{l}\text { M. rossi- } \\
\text { cum }\end{array}$ & $\begin{array}{c}\text { T. nobili- } \\
\text { tata }\end{array}$ \\
\hline A. clavis & A. rosea & $\begin{array}{l}\text { Enchy- } \\
\text { traeus sp. }\end{array}$ & $\begin{array}{c}\text { A. trape- } \\
\text { zoides }\end{array}$ & A. clavis & $\begin{array}{c}O . \\
\text { transpa- } \\
\text { danus }\end{array}$ & $\begin{array}{c}O . \\
\text { ligustici }\end{array}$ & $\begin{array}{c}\text { A. trape- } \\
\text { zoides }\end{array}$ & $\begin{array}{c}\text { A. } \\
\text { haemor- } \\
\text { rhoidalis }\end{array}$ \\
\hline $\begin{array}{c}\text { T. nobili- } \\
\text { tata }\end{array}$ & $\begin{array}{c}\text { A. trape- } \\
\text { zoides }\end{array}$ & $\begin{array}{c}\text { A. trape- } \\
\text { zoides }\end{array}$ & A. rosea & $\begin{array}{c}\text { A. trape- } \\
\text { zoides }\end{array}$ & $\begin{array}{c}\text { M. rossi- } \\
\text { cum }\end{array}$ & $\begin{array}{c}\text { M. rossi- } \\
\text { cum }\end{array}$ & $\begin{array}{c}\text { Enchy- } \\
\text { traeus sp. }\end{array}$ & $\begin{array}{l}\text { G. proxi- } \\
\text { mus }\end{array}$ \\
\hline \multicolumn{9}{|c|}{ Three species with the smallest value of the canonical axes } \\
\hline $\begin{array}{c}M . \\
\text { sjaelan- } \\
\text { dicum }\end{array}$ & $\begin{array}{c}D . \\
\text { octaedra }\end{array}$ & A. rosea & A. clavis & $\begin{array}{c}O . \\
\text { transpa- } \\
\text { danus }\end{array}$ & $\begin{array}{l}\text { P. incon- } \\
\text { stans }\end{array}$ & $\begin{array}{c}M . \\
\text { sjaelan- } \\
\text { dicum }\end{array}$ & A. clavis & $\begin{array}{c}M . \\
\text { sjaelan- } \\
\text { dicum }\end{array}$ \\
\hline $\begin{array}{c}D . \\
\text { octaedra }\end{array}$ & $\begin{array}{c}\text { T. nobili- } \\
\text { tata }\end{array}$ & $\begin{array}{c}D . \\
\text { octaedra }\end{array}$ & $\begin{array}{l}\text { G. proxi- } \\
\text { mus }\end{array}$ & $\begin{array}{l}\text { P. ferrugi- } \\
\quad \text { neum }\end{array}$ & $\begin{array}{c}M . \\
\text { sjaelan- } \\
\text { dicum }\end{array}$ & $\begin{array}{l}\text { Enchy- } \\
\text { traeus sp. }\end{array}$ & A. rosea & $\begin{array}{l}\text { P. incon- } \\
\text { stans }\end{array}$ \\
\hline $\begin{array}{c}\text { A. trape- } \\
\text { zoides }\end{array}$ & S. brunnea & $\begin{array}{c}\text { C. } \\
\text { lateralis }\end{array}$ & $\begin{array}{c}M . \\
\text { sjaelan- } \\
\text { dicum }\end{array}$ & $\begin{array}{l}\text { P. incon- } \\
\text { stans }\end{array}$ & A. rosea & A. clavis & $\begin{array}{c}\text { M. melo- } \\
\text { lontha }\end{array}$ & $\begin{array}{l}\text { P. ferrugi- } \\
\text { neum }\end{array}$ \\
\hline
\end{tabular}

Table 5. Results of regression analysis of the effect of environmental parameters on spatial components of the macrofauna community variation (statistically significant predictors are presented)

\begin{tabular}{|c|c|c|c|c|c|c|c|c|c|}
\hline \multirow{2}{*}{$\begin{array}{l}\text { Parameters } \\
\text { of regression } \\
\text { models }\end{array}$} & \multicolumn{3}{|c|}{$\begin{array}{r}\text { Broad-scale } \\
\text { component }\end{array}$} & \multicolumn{3}{|c|}{$\begin{array}{l}\text { Medium-scale } \\
\text { component }\end{array}$} & \multicolumn{3}{|c|}{$\begin{array}{l}\text { Fine-scale } \\
\text { component }\end{array}$} \\
\hline & RDA1 & RDA2 & RDA3 & RDA1 & RDA2 & RDA3 & RDA1 & RDA2 & RDA3 \\
\hline $\begin{array}{l}\text { Edaphic } \\
\text { principal components }\end{array}$ & 3 & 7,8 & 5,7 & 2 & $1,6,7,8$ & $3,4,7,8$ & 2,5 & $2,3,5$ & 1 \\
\hline $\begin{array}{c}\text { Vegetational } \\
\text { principal components }\end{array}$ & $1,3,4,5,6$ & - & - & - & 4,6 & 5,6 & 5 & 6 & $5,6,7$ \\
\hline$R_{a}^{2}$ & 0.38 & 0.23 & 0.15 & 0.14 & 0.34 & 0.29 & 0.32 & 0.27 & 0.24 \\
\hline$p$-level & 0.001 & 0.001 & 0.010 & 0.020 & 0.030 & 0.001 & 0.001 & 0.001 & 0.001 \\
\hline
\end{tabular}

predictors of the soil animal community structure, and out of 7 vegetation principal components, there are 6 reliable. The macrofauna community is most sensitive to minor principal components, that is, those characterized by relatively small eigenvalues. This result is valid both for the edaphic indicators and for the vegetation indicators. Thus, principal component 8 , characterized by the variation in humidity, temperature and electrical conductivity of the soil, explains only $3.8 \%$ of the total variation in soil properties but plays a key role in the structuring of the macrofauna community. Principal component 6 explains $4.31 \%$ of the total variation in vegetation indicators, but the macrofauna community is most sensitive to its variability. The essential interpretation of this component is quite "marginal" in relation to the general ecological situation in the investigated oak forest. This component reflects the ratio of paludants and ruderants in the vegetation community. To explain the results, it can be assumed that the character of the main variability of ecological conditions within the studied ecosystem lies within the ecological optimum of the species which compose the macrofauna community. Therefore, the variability of environmental regimes does not find a significant response in the structure of the community. Minor factors reflect relatively small fluctuations in the properties of the environment, but these changes are significant for the optimal framework for the soil animals of this community.

It is also important to note that, at some spatial levels, interspecies interactions play an important role in the structuring of species complexes (SCHOENER, 1974; WILSON and HaBIBA, 1995; BelyeA and LANCASTER, 1999; ZhuKov and GubANOva, 2015). In addition to environ- 
mental factors, for describing the organization of the soil animal community, there were used PCNM-variables. It should be noted that the spatial PCNM-variables explain significantly more variations of the community (19.9\%), than edaphic factors $(4.1 \%)$ and vegetation factors (3.2\%). At the same time, the environmental factors are characterized by a considerable spatial structuring. Of the $10.0 \%$ variability of the of soil animal community caused by soil factors, the individual component corresponds to $2.2 \%$, while $7.8 \%$ is explained by spatially structured soil factors. The entire vegetation component determining the structure of the community is spatially structured. For the earthworm community, a slightly different picture was observed: $33.0 \%$ of the community variation was explained by the environmental factors and only $1.8 \%$ by the spatial component (JIMÉNEZ et al., 2014). The authors believe that such a result is in accordance with the Hutchinson model for community control by environmental factors. It can be assumed, that the community we have studied is organized more under the influence of factors of a neutral nature. However, the spatial component of variation cannot be fully compared with the neutral component of the structuring of the community. Thus, the inclusion of soil data significantly reduced the amount of variation in the structure of the community, explained by the distribution, which resulted in reducing the importance of the 'neutral' component (BALDECK et al., 2013, CHANG et al., 2013).

In its turn, the spatial component of the community variation was divided into three scale components: finescale, medium-scale and broad-scale. The regression analysis revealed that the explained variance decreases from broad-scale component to detailed-scale component. Interspecific interactions such as competition and predation, differences in the individual plot and dispersion restrictions may influence the structure of the community of soil animals at small-scale levels. It may be assumed that the broad-scale component, and to a lesser degree - mediumscale component, reflect the variation in spatially structured environmental factors, whereas the fine-scale component can be interpreted more closely as the one which reflects the neutral aspect of the structuring of the community. This result was obtained in a study of the macrofauna of the sandy steppes (ZHukov et al., 2016). For the studied community, different scale components of spatial variation do not differ significantly in the degree of their consistency with environmental factors (Table 5). For broad-scale component, environmental factors of a vegetational nature are more important, for medium-scale component, edaphic factors are more important, for fine-scale component, both vegetation and edaphic are equally important. It should be noted that the spatial scale of the components is conditional. It is quite possible to expect the presence of dynamics in the processes of the macrofauna community of a neutral character, at a level that is designated in this work as 'broad-scale'. This is quite natural, since the community of soil animals is represented by ecological groups which are quite varied from the point of view of their migratory ability (ZHukov, 2015). Large litter-dwelling arthropods are able to move significant distances, whereas smaller or endogeic forms have a much narrower individual range. This assumption is confirmed by the qualitative composition of the species, which mark different RDA measurements. For broad-scale components, the markers are the litter animals and the endogeic earthworm A. trapezoides, which prefers the upper soil horizons. Among the markers for the fine-scale component, are the mainly endogeic or anecic animals.

Variations in the structure of the community under the influence of edaphic and vegetation factors can be classified as a deterministic impact, which operates within the framework of the theory of ecological niche. The spatial component of variation can be attributed to the effects of factors of a neutral nature. However, it should be noted, that the spatial variation in the vegetation community is also subject to the action of deterministic and neutral factors. This manifests itself in their spatial structure. The spatial variation in soil properties also has a similar nature. The soil as a habitat experiences the structuring influence of the vegetation cover, which gives rise to the spatial patterns of soil properties.

\section{Conclusion}

As a result of the research conducted, it was established that the causes of the structuring the soil macrofauna community are edaphic, vegetation and spatial factors. The role of these factors is different on fine-scale, medium-scale and broad-scale spatial levels. For the broad-scale components, environmental factors of a vegetational nature are more important, for the medium-scale components, edaphic factors are more important, for the fine-scale, both vegetation and edaphic factors are important. The broad-scale effects of variation in distribution manifest themselves in different ways for representatives of various ecological groups of macrofauna. The distributional patterns for litter invertebrates are most significant at the broad and medium scales, and for endogeic and anecic soil animals, they are most significant at the fine-scale.

A promising direction for further research on the problem discussed here is to study the relative effects of edaphic and vegetational factors on the structuring of soil macrofauna communities in different ecological conditions - such as gradient of the soil humidity and soil fertility. The key task is to assess the sensitivity of the macrofauna species, which may be explained by their ecological traits.

\section{Acknowledgements}

The authors are grateful to the staff of 'Dniprovsko-Orilsky' Nature Reserve for their support and assistance with this research. We thank Paul Bradbeer for checking the English text and the two anonymous reviewers for helping us to improve the earlier versions of this paper. 


\section{References}

Adler, P.B., Hillerislambers, J., Levine J.M., 2007. A niche for neutrality. Ecology Letters, 10: 95-104.

Amarasekare, P., 2003. Competitive coexistence in spatially structured environments: a synthesis. Ecology Letters, 6: $1109-1122$

Anderson, J.M., 1975. The enigma of soil animal species diversity. In VAneK, J. (eds). Progress in soil zoology. Prague: Czech, Academy of Sciences, p. 51-57.

ANDERSON, M.J., 2011. Navigating the multiple meanings of $\beta$-diversity: a roadmap for the practicing ecologist. Ecology Letters, 14: 19-28.

Baldeck, C.A., Harms, K.E., Yavitt, J.B., John, R., Turner, B.L., Valencia, R., Navarrete, H., Davies, S.J., Chuyong, G.B., Kenfack, D., Thomas, D.W., Madawala, S. Gunatilleke, N., Gunatilleke, S., Bunyavejchewin, S., Kiratiprayoon, S., Yaacob, A., Supardi, M.N., DalLING, J.W., 2013. Soil resources and topography shape local tree community structure in tropical forests. In Proceedings of the Royal Society B, 280 (1753): 2012-2032.

Barot, S., Gignoux, J., 2004. Mechanisms promoting plant coexistence: can all the proposed processes be reconciled? Oikos, 106: 185-192.

BELGARD, A.L., 1950. Lesnaya rastitel'nost' yugo-vostoka USSR [Forest vegetation of the south-eastern part of Ukraine]. Kyiv: KGU im. Shevchenko Press. 263 p.

Belgard, A.L., 1971. Stepnoe lesovedenie [Steppe forestry]. Moskva: Lesnaya promyshlennost'. $336 \mathrm{p}$.

Belyea, L.R., LANCASTER, J., 1999. Assembly rules within a contingent ecology. Oikos, 86 (3): 402-416.

Berg, M.P., 2012. Patterns of biodiversity at fine and small spatial scales. In WaLl, D.H., BARDGETT, R.D., BEHANPelletier, V., Herrick, J.E., Jones, T.H., Ritz, K., Six, J., Strong, D.R., van der Putten, W.H. (eds). Soil ecology and ecosystem services. Oxford, UK: Oxford University Press, p. 136-152.

Berg, M.P., Bengtsson, J., 2007. Temporal and spatial variability in soil food web structure. Oikos, 116: 1789-1804.

Blanchet, F.G., Bergeron, J.A.C., Spence, J.R., He, F. 2013. Landscape effects of disturbance, habitat heterogeneity and spatial autocorrelation for a ground beetle $(\mathrm{Ca}-$ rabidae) assemblage in mature boreal forest. Ecography, 36: 636-647.

Blanchet, F.G., Legendre, P., Borcard, D., 2008. Forward selection of explanatory variables. Ecology, 89 (9): 2623-2632.

Borcard, D., Legendre, P., 1994. Environmental control and spatial structure in ecological communities: An example using oribatid mites (Acari, Oribatei). Environmental and Ecological Statistics, 1: 37-61.

Borcard, D., Legendre, P., Avois-JaCquet, C., Tuosimoto, H., 2004. Dissecting the spatial structure of ecological data at multiple scales. Ecology, 85: 1826-1832.

Borcard, D., Legendre, P., Drapeau, P., 1992. Partialling out the spatial component of ecological variation. Ecology, 73: 1045-1055.

BRYGADYRENKO, V.V., 2015. Evaluation of the ecological niche of some abundant species of the subfamily Platyninae (Coleoptera, Carabidae) against the background of eight ecological factors. Folia Oecologica, 42: 75-88

BRYGADYRENKo, V.V., 2016. Effect of canopy density on litter invertebrate community structure in pine forests. Ekológia (Bratislava), 35 (1): 90-102.
BuzuK, G.N., 2017. Fitoindikaciya s primeneniem ekologicheskikh shkal i regressionnogo analiza: ekologicheskiu indeks [Phytoindication with ecological scales and regression analysis: environmental index]. Vestnik Farmacii, 2 (76): 31-37.

Cadotte, M.W., Fukami, T., 2005. Dispersal, spatial scale and species diversity in a hierarchically structured experimental landscape. Ecology Letters, 8: 548-557.

Caruso, T., Taormina, M., Migliorini, M., 2012. Relative role of deterministic and stochastic determinants of soil animal community: a spatially explicit analysis of oribatid mites. Journal of Animal Ecology, 81(1): 214-221.

Chang, L., Zeleny, D., Li, C., Chiu, S., Hsieh, C., 2013. Better environmental data may reverse conclusions about niche- and dispersal-based processes in community assembly. Ecology, 94: 2145-2151.

Chase, J.M., 2003. Community assembly: when should history matter? Oecologia, 136: 489-498.

Chave, J., 2004. Neutral theory and community ecology. Ecology Letters, 7: 241-253.

Clark, J.S., 2012. The coherence problem with the unified neutral theory of biodiversity. Trends in Ecology and Evolution, 27: 199-203.

DeCAËns, T., JimÉnez, J.J., Rossi, J.-P., 2009. A null-model analysis of the spatio-temporal distribution of earthworm species assemblages in Colombian grasslands. Journal of Tropical Ecology, 25 (4): 415-427.

DeCAËNs, T., Rossi, J.-P., 2001. Spatio-temporal structure of earthworm community and soil heterogeneity in a tropical pasture. Ecography, 24 (6): 671-682.

DiduH, Y.P., 2012. Prinzypy bioindicatzii [The principles of bioindication]. Kyiv: Naukova dumka. 344 p.

Didukh, Y.P., Fitsailo, T.V., Korotchenko, I.A., YaKushENKo, D.M., PashKeVyCh, N.A., 2011. Biotopi lisovoi ta lisostepovoi zon Ukriiny [Biotopes of forest and foreststeppe zones of Ukraine]. Kyiv: LLC MACROS. 288 p.

DiDUKH, Y.P., 2011. The ecological scales for the species of Ukrainian flora and their use in synphytoindication. Kyiv: Phytosociocentre. $176 \mathrm{p}$.

Digel, C., Curtsdotter, A., Riede, J., Klarner, B., Brose, U., 2014. Unravelling the complex structure of forest soil food webs: higher omnivory and more trophic levels. Oikos, 123: 1157-1172.

Dinno, A., 2012. paran: Horn's test of principal components/factors. R package version 1.5.1. [cit. 2017-11-03]. https://CRAN.R-project.org/package=paran

Dornelas, M., 2010. Disturbance and change in biodiversity. Philosophical Transactions of the Royal Society B, 365: 3719-3727.

Dornelas, M., Connolly S.R., Hughes T.P., 2006. Coral reef diversity refutes the neutral theory of biodiversity. Nature, 440: 80-82.

DraKe, J.A., 1990. Communities as assembled structures: do rules govern pattern? Trends in Ecology and Evolution, 5: 159-164.

Dray, S., Legendre, P., Peres-Neto, P., 2006. Spatial modelling: a comprehensive framework for principal coordinate analysis of neighbour matrices (PCNM). Ecological Modelling, 196: 483-493.

DraY, S. with contributions of Legendre, P., Blanchet, G., 2016. packfor: forward selection with permutation (Canoco p. 46). $R$ package version 0.0-8/r136. [cit. 201711-03]. https://R-Forge.R-project.org/projects/sedar/ 
Dvořáková, J., Horsák, M., 2012. Variation of snail assemblages in hay meadows: disentangling predictive power of abiotic environment and vegetation. Malacologia, 55: 151-162.

EllenBerG, H., 1974. Zeigerwerte der Gefässpflanzen Mitteleuropas. Scripta geobotanica, 9. Göttingen: Göltze. 197 p.

Ettema, C.H., Rathbun, S.L., Coleman, D.C., 2000. On spatiotemporal patchiness and the coexistence of five species of Chronogaster (Nematoda: Chronogasteridae) in a riparian wetland. Oecologia, 125: 444-452.

EtTema, C., WardLe, D.A., 2002. Spatial soil ecology. Trends in Ecology and Evolution, 17: 177-183.

Ettema, C.H., Yeates, G.W., 2003. Nested spatial biodiversity patterns of nematode genera in a New Zealand forest and pasture soil. Soil Biology and Biochemistry, 35 (2): 339-342.

FUKami, T., 2010. Community assembly dynamics in space. In Verhoef, H.A., Morin, P.J. (eds). Community ecology: processes, models, and applications. Oxford: Oxford University Press, p. 45-54.

Gazol, A., Ibanez, R., 2010. Plant species composition in a temperate forest: multi-scale patterns and determinants. Oecologia, 36: 634-644.

Gholami, S., Sayad, E., Gebbers, R., Schirrmann, M., Joschко, M., TimmeR, J., 2016. Spatial analysis of riparian forest soil macrofauna and its relation to abiotic soil properties. Pedobiologia, 59 (1): 27-36.

Gilyarov, M.S., Folkmanova, B., 1957. Gubonogie mnogonozhki (Chilopoda) stepnoî zony jugo-vostoka Evropejskoî chasti SSSR kak pokazateli pochvennykh usloviî $\mathrm{v}$ lesonasazhdeniyakh [Centipedes (Chilopoda) of the steppe zone in the southeast of the European part of the USSR as indicators of soil conditions in forest stands]. Izvestiya Akademii nauk SSSR, Seriya Biologicheskaya, 2: $211-219$.

HorN, J.L., 1965. A rationale and a test for the number of factors in factor analysis. Psychometrika, 30: 179-185.

Horsák, M., HáJeK, M., TichÝ, L., JuŘičKová, L., 2007. Plant indicator values as a tool for land mollusc autecology assessment. Acta Oecologica, 32: 161-171.

Hu, Y.-H., D.-Y. Sheng, Y.-Z. Xiang, Z.-J. Yang, D.-P. Xu, N.-N. Zhang, ShI, L.-L., 2013. The environment, not space, dominantly structures the landscape patterns of the richness and composition of the tropical understory vegetation. PLoS ONE, 8:e81308.

Hubbell, S.P., 2001. The unified neutral theory of biodiversity and biogeography. Princeton, New Jersey, USA: Princeton University Press. 392 p.

Hutchinson, G.E., 1957. Concluding remarks. Cold Spring Harbor Symposia on Quantitative Biology, 22: 415-427.

Hutchinson, G.E., 1965. The niche: an abstractly inhabited hypervolume. In Hutchinson, G.E. (eds). The ecological theatre and the evolutionary play. New Haven: Yale University Press, p. 26-78.

IgOndoví, E., MajZlan, O., 2015. Assemblages of ground beetles (Carabidae, Coleoptera) in peatland habitat, surrounding dry pine forests and meadows. Folia Oecologica, 42: 21-28.

JimÉneZ, J.J., DeCAëns, T., Rossi, J.P., 2006. Stability of the spatio-temporal distribution and niche overlap in neotropical earthworm assemblages. Acta Oecologica, 30 (3): 299-311.

JimÉnEZ, J.J., DeCAËNS, T., Rossi, J.-P., 2012. Soil environ- mental heterogeneity allows spatial co-occurrence of competitor earthworm species in a gallery forest of the Colombian 'Llanos'. Oikos, 121: 915-926.

Jiménez, J. J., Decaëns, T., Lavelle, P., Rossi, J.-P., 2014. Dissecting the multi-scale spatial relationship of earthworm assemblages with soil environmental variability. BMC Ecology, 14:26.

Jorgensen, H.B., Elmholt, S., Petersen, H., 2003. Collembolan dietary specialisation on soil grown fungi. Biology and Fertility of Soils, 39: 9-15.

KARPACHEVSKy, L.O., 2005. Ekologicheskoe pochvovedenie [Ecological pedology]. Moscow: Geos. 336 p.

Kirby, K.N., Gerlanc, D., 2013. BootES: an R package for bootstrap confidence intervals on effect sizes. Behavior Research Methods, 45: 905-927.

KRIVOLUTSKY, D.A., 1994. Pochvennaya fauna v ekologicheskom kontrole [Soil fauna in ecological control]. Moskva: Nauka. 240 p.

Laliberte, E., Paquette, A., Legendre, P., Bouchard, A., 2009. Assessing the scale-specific importance of niches and other spatial processes on beta diversity: a case study from a temperate forest. Oecologia, 159: 377-388.

Lawton, J., 1999. Are there general laws in ecology? Oikos, 84: $177-192$

LAZORÍK, M., Kula, E., 2015. Impact of weather and habitat on the occurrence of centipedes, millipedes and terrestrial isopods in mountain spruce forests. Folia Oecologica, 42: 103-112.

LeGENDRE, P., 1993. Spatial autocorrelation: trouble or new paradigm? Ecology, 74: 1659-1673.

Legendre, P., Borcard, D., Peres-Neto, P.R., 2005. Analyzing beta diversity: partitioning the spatial variation of community composition data. Ecological Monographs, 75: 435-450.

Legendre, P., Mi, X., Ren, H., Ma, K., Yu, M., Sun, I.-F., He, F., 2009. Partitioning beta diversity in a subtropical broadleaved forest of China. Ecology, 90: 663-674

Maraun, M., Martens, H., Migge, S., Theenhaus, A., SCHEU, S., 2003. Adding to 'the enigma of soil animal diversity': fungal feeders and saprophagous soil invertebrattes prefer similar food substrates. European Journal of Soil Biology, 39: 85-95.

Mathieu, J., Rossi, J.P., Grimaldi, M., Mora, P., Lavelle, P., Rouland, C., 2004. A multi-scale study of soil macrofauna biodiversity in Amazonian pastures. Biology and Fertility of Soils, 40: 300-305.

McArdle, B.H., Anderson, M.J., 2004. Variance heterogeneity, transformations and models of species abundance: a cautionary tale. Canadian Journal of Fisheries and Aquatic Sciences, 61: 1294-1302.

Nekola, J.C., 2003. Large-scale terrestrial gastropod community composition patterns in the Great Lakes region of North America. Diversity and Distributions, 9: 55-71.

Ondina, P., Hermida, J., Outeiro, A., Mato, S., 2004. Relationships between terrestrial gastropod distribution and soil properties in Galicia (NW Spain). Applied Soil Ecology, 26 (1): 1-9.

PenNisi, B. V., van Iersel, M., 2002. 3 ways to measure medium EC. GMPro, 22 (1): 46-48.

Polláková, N., ŠimanskÝ, V., Jonczak, J., 2017. Characteristics of physical properties in soil profiles under selected introduced trees in the Nature Reserve Arboretum Mlyňany, Slovakia. Folia Oecologica, 44: 78-86.

R CORE TeAm, 2017. R: a language and environment for 
statistical computing. Vienna, Austria: R Foundation for Statistical Computing. [cit. 2017-10-04]. https://www.Rproject.org/.

RAUNKIER, C., 1934. The life forms of plants and statistical plant geography. Oxford: Clarendon Press. 632 p.

Rossi, J.P., 2003. Clusters in earthworm spatial distribution. Pedobiologia, 47 (5-6): 490-496.

Rossi, J.-R., LaVelle, P., Tondoh, J.E., 1996. Statistical tool for soil biology. XI. Autocorrelogram and Mantel test. European Journal of Soil Biology, 32: 195-203.

SAETRE, P., 1999. Spatial patterns of ground vegetation, soil microbial biomass and activity in a mixed spruce-birch stand. Ecography, 22: 183-192

Schneider, K., Migge, S., Norton, R.A., Scheu, S., LanGel, R., Reineking, A., Maraun, M., 2004. Trophic niche differentiation in soil microarthropods (Oribatida, Acari): evidence from stable isotope ratios $(\mathrm{N}-15 / \mathrm{N}-14)$. Soil Biology and Biochemistry, 36: 1769-1774.

SCHOENER, T.W., 1974. Resource partitioning in ecological communities. Science, 185 (4145): 27-39.

Siefert, A., Ravenscroft, C., Weiser, M.D., Swenson, N.G., 2013. Functional beta-diversity patterns reveal deterministic community assembly processes in eastern North American trees. Global Ecology and Biogeography, 6: 682-691.

Soinenen, J., Lennon, J.J., Hillebrand, H., 2007. A multivariate analysis of beta diversity across organisms and environments. Ecology, 88: 2830-2838.

Stašıov, S., SvitoK, M., 2014. The influence of stand density on the structure of centipede (Chilopoda) and millipede (Diplopoda) communities in the submountain beech forest. Folia Oecologica, 41: 195-201.

TAKEDA, H., 1987. Dynamics and maintenance of Collembolan community structure in a forest soil system. Researches on Population Ecology, 29: 291-346.

TARasov, V.V., 2012. Flora Dnipropetrovs 'koi'ta Zaporiz'koi' oblastej. Sudynni roslyny. Biologo-ekologichna harakterystyka vydiv [Flora of Dnipropetrovsk and Zaporizhzhya regions. Vascular plants. Biological and ecological characteristics of the species]. Dnipropetrovsk: Dnipropetrovsk University Press. 296 p.

TSATSENKIN, I.A., 1970. Ekologicheskaya otsenka kormovykh ugodiy Karpat i Balkan po rastitel'nomu pokrovu [Ecological evaluation of the fodder lands of the Carpathians and the Balkans on vegetation]. Moscow: Institute of Forages. $192 \mathrm{p}$

Vadunina, A. F., Korchagina, S.A., 1986. Metody issledovaniya fizicheskikh svoǔstv pochv [Methods for research of physical properties of the soil]. Moskva: Agropromizdat. $416 \mathrm{p}$.

ViKeTOFT, M., 2013. Determinants of small-scale spatial patterns: importance of space, plants and abiotics for soil nematodes. Soil Biology and Biochemistry, 62: 92-98.

WARDLE, D.A., 2006. The influence of biotic interactions on soil biodiversity. Ecology Letters, 9: 870-886.

Warren, M.W., Zou, X., 2002. Soil macrofauna and litter nutrients in three tropical tree plantations on a disturbed site in Puerto Rico. Forest Ecology and Management, 170: $161-171$.

Whalen, J.K., 2004. Spatial and temporal distribution of earthworm patches in corn field, hayfield and forest systems of southwestern Quebec, Canada. Applied Soil Ecology, 27 (2): 143-151.
Whittaker, R.H., 1960. Vegetation of the Siskiyou Mountains, Oregon and California. Ecological Monographs, 30: 279-338.

WhitTAKeR, R.H., 1972. Evolution and measurement of species diversity. Taxonomy, 21: 213-251.

Widenfalk, L.A., Bengtsson, J., Berggren, Å., Zwiggelaar, K., Spijkman, E., Huyer-Brugman, F., Berg, M.P., 2015. Spatially structured environmental filtering of collembolan traits in late successional salt marsh vegetation. Oecologia, 179 (2): 537-549.

Wilson, J.B., HaBiBa, G., 1995. Limitation to species coexistence: evidence for competition from field observations, using a patch model. Journal of Vegetation Science, 6: 369-376.

Yorkina, N., Maslikova, K., Kunah, O., Zhukov, O., 2018. Analysis of the spatial organization of Vallonia pulchella (Muller, 1774) ecological niche in Technosols (Nikopol manganese ore basin, Ukraine). Ecologica Montenegrina, 17: 29-45.

Zhukov, A., ZadorozhnaYa, G., 2016. Spatial heterogeneity of mechanical impedance of a typical chernozem: the ecological approach. Ekológia (Bratislava), 35: 263-278.

Zhuкоv, A.V., 2015. Foromorfy v sisteme ekomorf pochvennykh zhivotnykh [Phoromorphs in the ecomorph system of soil animals]. The Journal of V.N. Karazin Kharkiv National University. Series: Biology, 25: 254-266.

Zhukov, A.V., Kunakh, O.N., Novikova, V.A., 2015. Ekomorficheskaya organizaciya soobshchestv mezopedobiontov dubnyaka so svezhim raznotrav'em na arene $r$. Dnepr [The ecomorphic organization of the mesopedobiont community of an oak forest with the fresh grass in arena of the Dnieper river]. The Kharkov Entomological Society Gazette, 23 (2): 39-53.

Zhukov, A.V., Shtirts, A.D., Zadorozhnaja, G.A., Kunah, O.N., 2013. Frakcionirovanie prostranstvennoj variacii soobshchestva pancirnyh kleshchej (Acari: Oribatida) v pochve sel'skohozyajstvennogo polya $\mathrm{v}$ usloviyah stepnoj zony Ukrainy [Fractionation of oribatid mites (Acari: Oribatida) community spatial structure in the soil of an agricultural field in Ukraine's steppe zone]. Problems of Ecology and Environmental Protection of Technogenic Region, 1 (13): 87-105.

Zhukov, O.V., Gubanova, N.L., 2015. Riznomanittya ta dynamika uhrupovan' zemnovodnykh zaplavnykh ekosystem r. Samara-Dniprovs'ka [Diversity and dynamics of amphibians in floodplain ecosystems of the Samara river]. Visnyk of Dnipropetrovsk University. Biology, Ecology, 23 (1): 66-73.

Zhukov, O.V., Kunah, O.M., Dubinina, Y.Y., GanZha, D.S., 2017. Riznomanittya ta fitoindykatsiyni mozhlyvosti roslynnoho uhrupovannya [Diversity and phytoindication capacity of a plant community]. Ukrainian Journal of Ecology, 7 (4): 81-99.

Zhukov, O.V., Kunah, O.N., Novikova, V.A., 2016. Funkcional'naya struktura soobshchestva mezopedobiontov dernovo-borovoj pochvy areny r. Dnepr [The functional organisation of the mesopedobionts community of sod pinewood soils on arena of the river Dnepr]. Visnyk of Dnipropetrovsk University. Biology, Ecology, 24 (1): 26-39.

Received December 31, 2017 Accepted April 10, 2018 